\section{JURNAL ABDIMAS

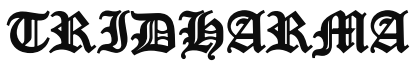 AHA}

\title{
PENGARAHAN DAN MOTIVASI GUNA PERSIAPAN MENGHADAPI PERSAINGAN DUNIA KERJA PADA SISWA SMK BINA HARAPAN CISEENG
}

\author{
Ayu Puspa Lestiyadi ${ }^{1}$, Tutri Indraswari ${ }^{2}$, Shela Puspita Sari ${ }^{3}$, \\ Kartika Sari Dewi ${ }^{4,}$ Suryono ${ }^{5}$
}

Dosen ManajemenFakultas Ekonomi Universitas Pamulang

Email: dosen02505@unpam.ac.id, dosen02446@unpam.ac.id,dosen02512@unpam.ac.id, dosen02506@unpam.ac.id, dosen02742@unpam.ac.id

\begin{abstract}
ABSTRAK
Kegiatan Pengabdian Kepada Masyarakat ini bertujuan untuk memberikan pengarahan dan motivasi kepada siswa guna persiapan mengahadapi persaingan dunia kerja. Metode kegiatan yang digunakan adalah kerja sama dengan Kepala Sekolah SMK Bina Harapan, yang beralamat di Malang Nengah, Ciseeng dan memberikan pengarahan dan motivasi kepada siswa. Setelah di analisis, kami memberikan pengarahan dan motivasi dari mulai memberikan pengarahan bagaimana ruang lingkup persaingan di dunia kerja, apa saja yang harus di persiapkan oleh mereka sebagai calon lulusan SMK untuk menghadapi persaingan dunia kerja, serta tentang apa saja keahlian yang harus dimiliki oleh lulusan SMK. Hasil kegiatan menunjukan bahwa sebelum pelaksanaan PKM, para siswa SMK Bina Harapan belum mengetahui apa saja yang dapat dilakukan untuk dapat menghadapi persaingan kerja, namun setelah pelaksanaan kegiatan PKM ini diketahui para peserta setidaknya sudah mempunyai sedikit bekal dan dapat memahami tentang seperti apa persaingan di dunia kerja, apa saja yang harus mereka lakukan untuk mengahadapi persaingan dunia kerja dan keahlian apa saja yang harus dimiliki oleh lulusan SMK. Kegiatan PKM berperan positif dalam meningkatkan pengetahuan dan motivasi kepada siswa SMK Bina Harapan.
\end{abstract}

Kata Kunci : Pengarahan, Motivasi, Dunia Kerja

\section{ABSTRACT}

This Community Service activity aims to provide direction and motivation to students in preparation for the competitive world of work. The method of activity used is in collaboration with the Principal of SMK Bina Harapan, which is located in Malang Nengah, Ciseeng and provides direction and motivation to students. After the analysis, we provide direction and motivation from starting to provide direction on how the scope of competition in the world of work, what they must prepare as prospective SMK graduates to face the competition in the world of work, as well as about what skills must be possessed by SMK graduates. . The results of the activity showed that prior to the implementation of the PKM, the students of SMK Bina Harapan did not know what could be done to be able to face job competition, but after the implementation of this PKM activity it was known that the participants had at least a little knowledge and could understand what competition is like in the world of work. , what they have to do to face the competition in the world of work and what skills must be possessed by SMK graduates. PKM activities play a positive role in increasing knowledge and motivation for Bina Harapan Vocational High School students.

Keywords: Direction, Motivation, World of Work

\section{PENDAHULUAN}

Tujuan didirikannya Sekolah Menengah Kejuruan (SMK) tampaknya kian menjauh dari jangkauan. Lulusan SMK diharapkan memiliki kompetensi dan kemampuan vokasi yang sesuai dengan tuntutan dunia usaha maupun 


\section{JURNAL ABDIMAS

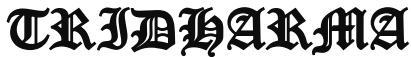

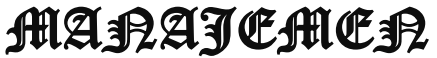

P-ISSN 2615-6849, E-ISSN 2716-070X

Jurnal ABDIMAS Vol.3,No.1,Desember 2021,Hal(86-91)

@ Prodi Manajemen Fakultas Ekonomi Universitas Pamulang

Email: abdimasjurnal.unpam@ gmail.com Telp: (021) 741-2566 dunia industri (DUDI), baik di level nasional maupun global. Dengan begitu, lulusan SMK sudah siap kerja.

Pada kenyataannya, jumlah pengangguran lulusan SMK terus meningkat. Bahkan, tingkat pngangguran SMK selalu berada di posisi teratas dibandingkan lulusan lain. Per Februari 2021, tingkat pengangguran keluaran dari SMK mencapai dua digit, yakni 11,45 persen, naik hampir 36 persen dibandingkan tahun sebelumnya.

Situasi pada 2020 memang tak bisa dijadikan patokan karena pandemic Covid-19 telah merenggut pekerjaan dari hampir 10 juta pengangguran. Sehingga, kenaikan jumlah penyerapan tenaga kerja 2020 sebanyak 1,03 juta (naik 10,5 persen dibandingkan tahun sebelumnya), jadi tak banyak berarti.

Namun, tingginya pengangguran dikalangan lulusan SMK sudah terjadi jauhjauh hari sebelumnya. Inilah yang kemudian memunculkan kekhawatiran yang jauh lebih mendasar, yakni tidak terjadinya link and match antara lulusan SMK dengan kebutuhan dunia usaha dan dunia indutri, seperti yang dicita-citakan semula.

Hal ini sudah di akui Menteri Ketenagakerjaan Ida Fauziyah. Padahal, sejak 2017 pemerintah telah menyusun Roadmap Pendidikan dan Pelatihan Vokasi 2017-2015. Peta jalan itu dimaksudkan agar SMK bisa menghasilkan lulusan yang sesuai dengan kebutuhan dunia usaha dan dunia industri.

Peta jalan itu memiliki empat focus kebijakan. Pertama, mendorong pemenuhan tenaga kerja untuk enam sektor prioritas; Kedua, mendorong tenaga kerja untuk program prioritas pemerintah; Ketiga, focus pada lembaga pendidikan dan pelatihan vokasi; Keempat, perbaikan fundamental pendidikan dan pelatihan vokasi.

Namun, tampaknya masih perlu waktu untuk melihat hasil perombakan perta jalan tersebut. bagaimana pun, pemerintah perlu bergegas agar tidak terjadi penumpukan lulusan SMK yang menganggur di masa mendatang.

Melihat analisis situasi di atas maka

SMK Bina Harapan harus melakukan pengarahan dan motivasi untuk persiapan menghadapi persaingan di dunia kerja pada calon lulusan SMK ini.

Kepedulian Lembaga Perguruan

Tinggi Kepada Masyarakat dalam rangka meningkatkan kualitas pendidikan merupakan Tri Dharma Perguruan Tinggi. Untuk merealisasikan proram tersebut di perlukan suatu rena yang dilakukan oleh Tenaga Pengajar. Program Pengabdian Kepada Masyarakat ini adalah Pengarahan Dan Motivasi Guna Persiapan Menghadapi Persaingan Dunia Kerja Pada Siswa SMK Bina Harapan.

\section{RUMUSAN MASALAH}

Dengan memperhatikan latar belakang yang telah dipaparkan diatas kami akan mengadakan pengabdian kepada masyarakat tepatnya di SMK Bina Harapan Ciseeng. Adapun rumusan masalah pada PKM ini adalah:

1. Bagaimana memberikan pengarahan kepada siswa SMK Bina Harapan guna mempersiapkan diri bersaing di dunia kerja

2. Bagaimana memberikan motivasi kepada siswa untuk mendalami skill yang mereka miliki?

\section{TUJUAN PELAKSANAAN}

1. Tujuan Umum

Yaitu memberikan pengarahan dan motivasi kepada siswa SMK Bina Harapan

2. Tujuan Khusus

a) Memberikan pengarahan tentang dunia kerja dan persaingannya

b) Memberikan solusi apa saja yang harus mereka persiapkan untuk menghadapi dunia kerja

c) Memberikan motivasi secara keseluruhan untuk siswa SMK Bina Harapan

\section{TINJAUAN PUSTAKA}

1. Pengertian Pengarahan

Pengertian Pengarahan (Directing)

Menurut Pendapat Para Ahli. Selain pengertian tersebut, beberapa ahli juga telah mengemukakan pendapatnya tentang apa yang disebut dengan pengarahan, diantaranya adalah : 


\section{JURNAL ABDIMAS

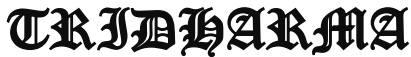 AHA}

P-ISSN 2615-6849, E-ISSN 2716-070X

Jurnal ABDIMAS Vol.3,No.1,Desember 2021,Hal(86-91)

@ Prodi Manajemen Fakultas Ekonomi Universitas Pamulang

Email: abdimasjurnal.unpam@ gmail.com Telp: (021) 741-2566
- Siswanto, berpendapat bahwa pengarahan adalah satu kegiatan yang berhubungan dengan pemberian perintah dan saran.

- Amir, berpendapat bahwa pengarahan adalah membuat pegawai mengerjakan apa yang seharusnya dikerjakan dan memotivasinya untuk mencapai tujuan organisasi, ada yang mengatur, mengarahkan, memotivasi, memberikan sanksi, dan lain sebagainya.

\section{Pengertian Motivasi}

Dikutip dari buku karya Hamzah B. Uno, istilah motivasi berasal dari kata motif yang dapat diartikan sebagai kekuatan yang terdapat dalam diri individu, yang menyebabkan tersebut bertindak atau berbuat. Motif tidak dapat diamati secara langsung, tetapi dapat diinterprestasikan dalam tingkah lakunya, berupa rangsangan, dorongan, atau pembangkit tenaga munculnya suatu tingkah laku tertentu.

Berkaitan dengan pengertian motivasi, beberapa psikologi menyebutkan motivasi sebagai konstruk hipotesis yang digunakan untuk menjelaskan keinginan, arah, intensitas, dan keajegan perilaku yang diarahkan oleh tujuan.

3. Persaingan

Secara umum persaingan ( competition ) merupakan suatu proses sosial ketika ada dua pihak atau lebih saling berlomba dan berbuat sesuatu untuk mencapai kemenangan tertentu. Persaingan ini dapat terjadi bila terdapat beberapa pihak menginginkan sesuatu yang jumlahnya terbatas atau menjadi pusat perhatian umum.

\section{Dunia Kerja}

Dunia kerja adalah gambaran tentang beberapa jenis dan proporsi pekerjaan yang ada seperti dalam bidang pertanian, usaha dan perkantoran, rekayasa, kesehatan, militer kemasyarakatan, kerumah tanggaan, dan seni budaya. Dalam era globalisasi seluruh dunia kerja dan industeri berusaha meningkatkan efisiensi dan produktifitas kerja. Adanya peningkatan efisiensi dan produktifitas kerja menunjukkan bahwa perusahaan telah melaksanakan re-engineering dan re-strukturing dalam rangka mempersingkat proses produksi.

\section{METODE PELAKSANAAN}

Metode kegiatan ini berupa pengarahan dan motivasi guna persiapan menghadapi persaingan dunia kerja pada siswa Smk Bina Harapan ciseeng, berikut ini adalah tahapan kegiatan yang dilakukan:

1. Tahap Persiapan

Tahap persiapan yang dilakukan meliputi:

a. Survey awal, pada tahap ini dilakukan survei ke lokasi Sekolah SMK Bina Harapan yang beralamat di Jalan $H$. Usa No1, Malang Nengah, Ciseeng

b. Pemantapan dan penentuan lokasi dan sasaran. Setelah survey maka ditentukan lokasi pelaksanaan dan sasaran peserta kegiatan.

c. Penyusunan bahan/materi pengarahan dan motivasi guna persiapan menghadapi persaingan dunia kerja pada siswa Smk Bina Harapan Ciseeng

2. Tahap Pelaksanaan Penelitian

Tahap ini akan diberikan penjelasan mengenai dunia kerja

3. Tahap Penyuluhan

Untuk melaksanakan kegiatan tersebut digunakan beberapa metode penyuluhan yaitu:

a. Metode Ceramah

Metode ceramah dipilih untuk memberikan penjelasan tentang pengarahan dan motivasi guna persiapan menghadapi persaingan dunia kerja pada siswa Smk Bina Harapan Ciseeng

b. Metode Tanya Jawab

Metode Tanya jawab sangat penting bagi para siswa. Metode ini memungkinkan para siswa menggali ilmu pengetahuan tentang dunia kerja

peserta pelatihan. Metode ini memungkinkan para peserta menggali pengetahuan sebanyak- 


\section{JURNAL ABDIMAS

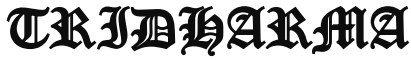

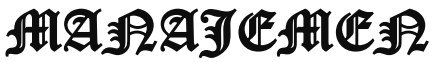

P-ISSN 2615-6849, E-ISSN 2716-070X

Jurnal ABDIMAS Vol.3,No.1,Desember 2021,Hal(86-91)

@ Prodi Manajemen Fakultas Ekonomi Universitas Pamulang

Email: abdimasjurnal.unpam@ gmail.com Telp: (021) 741-2566 banyaknya tentang cara pencegahan virus corona

c. Metode Simulasi

Metode simulasi ini diberikan kepada para siswa dengan memberikan memberika pengetahuan tentang hal apa saja yang bisa di lakukan untuk persiapan memasuki dunia kerja

\section{HASIL DAN PEMBAHASAN}

Setelah dilaksanakan pengarahan pengarahan dan motivasi guna persiapan menghadapi persaingan dunia kerja pada siswa smk bina harapan ciseeng, maka tingkat keberhasilan penyelenggaraan kegiatan Pengabdian Kepada Masyarakat ini dapat dilihat dari hasil evaluasi selama pelaksanaan kegiatan, yaitu:

1. Evaluasi proses yaitu untuk mengetahui pelaksanaan dari program yang dibuat serta keterlibatan peserta atau khalayak sasaran antara strategis selama mengikuti kegiatan. Evaluasi ini dilakukan dari awal sampai akhir kegiatan dengan melihat tanggapan peserta penjelasan dan contoh-contoh yang diberikan, melakukan sesi tanya jawab yang interkatif namun hanya ada beberapa siswa atau peserta yang belum bisa menangkap materi dengan baik dikarenakan usia.

2. Evaluasi hasil yaitu untuk mengetahui seberapa jauh tingkat keberhasilan tujuan yang telah dirumuskan, dapat dilihat dari respon (tanggapan) peserta terhadap pengarahan dan motivasi yang telah dilakukan pada saat kegiatan berlangsung.

Kegiatan dilakukan selama dua hari pada tanggal $19 \mathrm{~s} / \mathrm{d} 20$ November 2021 dihadiri siswa SMK Bina Harapan sebanyak 20 orang. Semua peserta mengikuti kegiatan secara penuh dikarenakan semua peserta antusias mengikuti kegiatan pengarahan dan motivasi. Dari respon (tanggapan peserta) yang diberikan meraka semua sangat berharap kegiatan Pengabdian Kepada Masyarakat seperti ini dalam dilakukan kembali pada periode-periode berikutnya. Adapun beberapa faktor pendorong terlaksananya kegiatan sosialisasi ini adalah sebagai berikut:

1. Dari pihak peserta (siswa SMK Bina Harapan) begitu antusias dalam mengikuti seluruh rangkaian kegiatan pengabdian pada masyarakat ini.

2. Pelaksanaan kegiatan ini dapat memberikan pengetahuan tambahan/menambah wawasan bagi peserta mengenai persiapan persaingan dunia kerja

3. Kesiapan dan semangat para peserta kegiatan ini begitu besar untuk mendapatkan pengetahuan yang disiapkan oleh panitia pelaksana.

4. Faktor pendorong lainnya adalah kesiapan anggota tim pelaksana yang telah menyiapkan diri, terutama dalam pemberi materi pada kegiatan pengabdian ini sangatlah interaktif dan memberikan suasana yang bersahaja.

\section{KESIMPULAN DAN SARAN KESIMPULAN}

Pelaksanaan kegiatan pengabdian kepada masyarakat oleh Lembaga Penelitian dan Pengabdian Masyarakat (LPPM) Universitas Pamulang yang dilakukan oleh dosen-dosen Universitas pada program studi manajemen telah berjalan dengan lancar dan mendapat sambutan hangat dari tempat pelaksanaan kegiatan ini yaitu SMK Bina Harapan, Ciseeng.

Harapan kami selaku dosen, dengan pengabdian ini dapat menambah pemahaman dan wawasan tentang bagaimana mempersiapkan diri untuk menghadapi persaingan dunia kerja.

Materi yang kami berikan yaitu tentang persaingan di dunia kerja, persiapan apa saja yang siswa SMK Bina Harapan dapat lakukan, dan keahlian apa saja yang harus di miliki oleh lulusan SMK.

\section{SARAN}

Dalam laporan kegiatan ini mungkin banyak kekurangan yang ada, untuk itu kami berharap masukan dan kritikan dalam rangka perbaikan untuk kegiatan-kegiatan pengabdian masyarakat di masa yang akan datang. Semoga kegiatan pengabdian masyarakat ini dapat bermanfaat bagi masyarakat sekitar Universitas Pamulang.

Akhirnya, kami mengucapkan terima kasih kepada seluruh pihak yang telah mendukung kegiatan yang kami laksanakan 


\section{JURNAL ABDIMAS

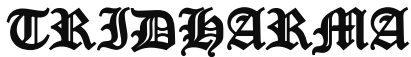

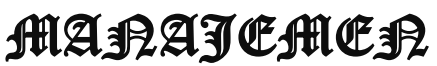

P-ISSN 2615-6849, E-ISSN 2716-070X

Jurnal ABDIMAS Vol.3,No.1,Desember 2021,Hal(86-91)

@ Prodi Manajemen Fakultas Ekonomi Universitas Pamulang

Email: abdimasjurnal.unpam@ gmail.com Telp: (021) 741-2566 dan kami mohon maaf apabila dalam laporan ini banyak ditemukan kekurangan.

\section{DAFTAR PUSTAKA.}

Hamzah B. Uno, "Teori Motivasi dan Pengukurannya", Edisi 1, Cetakan ke 14, PT. Bumi Aksara Jakarta, 2016

Pasaribu, V. L. D., Agrasadya, A., Shabrina, N., \& Krisnaldy, K. (2020). Menjadi Enterpreneur Muda Yang Memiliki Jiwa Leadership Untuk Menghadapi Masa Depan. Abdi Laksana: Jurnal Pengabdian Kepada Masyarakat, 1(1).

Pasaribu, V. L. D., Susanti, F., \& Hartuti, E. T. K. (2019). Memotivasi Siswa dan Siswi SMK Letris Indonesia di Dalam Menentukan Pilihan Untuk Melanjutkan Pendidikan Atau Bekerja Setelah Lulus Sekolah. Jurnal Pengabdian Dharma Laksana, 1(2), 161-172.

Pasaribu, V. L. D., Sulaiman, S., Sutiman, S., Thaharudin, T., \& Purnomo, B. Y. (2020). Pengenalan Letak Posyandu Terdekat Dikelurahan Pisangan Dengan Manajemen Pemasaran Revolusi 4.0 Untuk Meningkatkan Pengetahuan Masyarakat Letak Dan Fungsi Posyandu Terdekat Pada Kelurahan Pisangan. Dedikasi Pkm, l(1), 105-110.

Pasaribu, V. L. D., Oktrima, B., Prabowo, B., Arianto, N., \& Haryoko, U. B. (2020). Progam Pendampingan Dan Penyelenggaraan Pendidikan Anak Pada Usia Dini Terhadap Prestasi Belajar Dilingkungan Rt 020 Rw 009. Kel Giri Peni. Kec Wates. Yogyakarta. Jurnal Lokabmas Kreatif, 1(1), 71-75.

Pasaribu, V. L. D., Jannah, M., Fazar, M., Putra, S. P., Monalisa, M., \& Sofa, M. (2021). MENINGKATKAN PRODUKTIVITAS USAHA DIMASA PANDEMI PADA IBU PKK RT 004/003 KELURAHAN SAWAH BARU CIPUTAT,
TANGERANG SELATAN. $A b d i$ Laksana: Jurnal Pengabdian Kepada Masyarakat, 2(2), 295-301.

Pasaribu, V. L. D., Yuniati, H. L., Pranata, R., Sembayu, R., Purba, S. M., \& Nurbayani, T. T. A. (2021). MANAJEMEN KEUANGAN UNTUK MENGHADAPI DAN BERTAHAN DI ERA COVID 19. Jurnal Abdimas Tri Dharma Manajemen, 2(2), 12-18.

Pasaribu, V. L. D., Dwiyatni, A., Sabina, C., Ridwan, M., Gunawan, D. D., \& Noviani, B. C. (2021). EVALUASI PENERAPAN 3M DIMASA PANDEMIC COVID 19. Jurnal Abdimas Tri Dharma Manajemen, 2(2), 54-60.

Pasaribu, V. L. D., Syafei, A. N., Farhan, A., Aufaizah, A., Irani, C., \& Firtiayani, S. R. (2021). PENGARUH DISPLIN PROTOKOL KESEHATAN TERHADAP PENCEGAHAN PENULARAN VIRUS COVID19. Jurnal Abdimas Tri Dharma Manajemen, 2(2), 91-98.

Pasaribu, V. L. D., Septiani, F., Rahayu, S., Lismiatun, L., Arief, M., Juanda, A., ... \& Rahim, R. (2021). Forecast Analysis of Gross Regional Domestic Product based on the Linear Regression Algorithm Technique.

Priadi, A., Pasaribu, V. L. D., Virby, S., Sairin, S., \& Wardani, W. G. (2020). Penguatan Ekonomi Kreatif Berbasis Sumber Daya Desa Dikelurahan Rempoa. Abdi Laksana: Jurnal Pengabdian Kepada Masyarakat, 1(3), 356-35

Pasaribu, V. L. D., Priadi, A., Anismadiyah, V., Rahayu, S., \& Maduningtias, L. (2021). PENYULUHAN KREATIF DAN INOVATIF MENINGKATKAN MUTU PRODUKSI UMKM DI DESA BELEGA KABUPATEN GIANYAR. Pro Bono Jurnal Pengabdian Kepada Masyarakat, 1(02) 


\section{JURNAL ABDIMAS

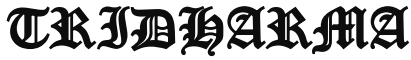

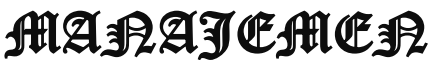

P-ISSN 2615-6849, E-ISSN 2716-070X

Jurnal ABDIMAS Vol.3,No.1,Desember 2021,Hal(86-91)

@Prodi Manajemen Fakultas Ekonomi Universitas Pamulang

Email: abdimasjurnal.unpam@gmail.com Telp: (021) 741-2566

\section{DOKUMENTASI KEGIATAN}

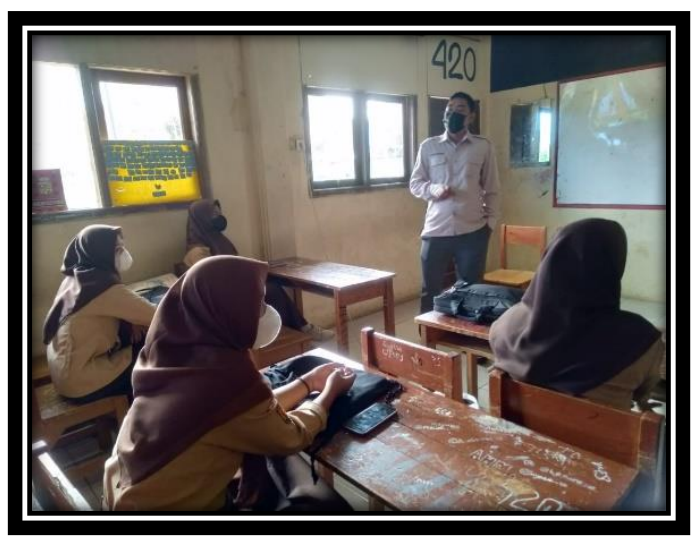

Pembukaan Oleh Wakil Kepala Sekolah SMK Bina Harapan Ciseeng

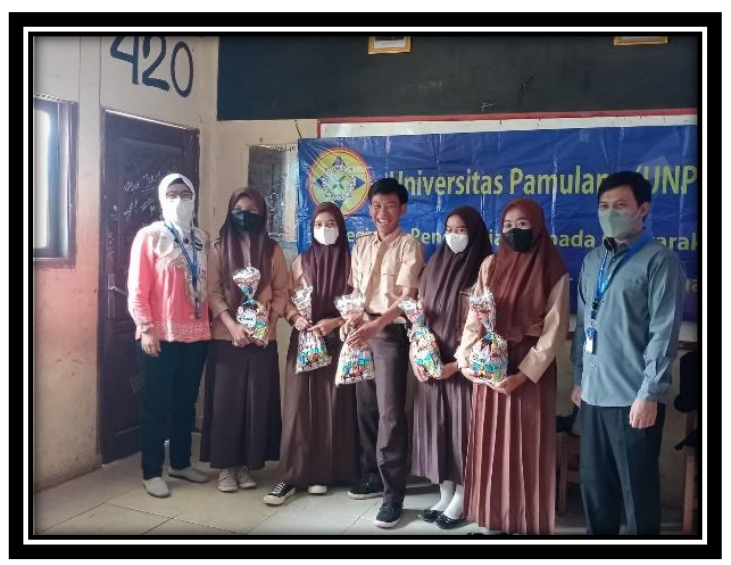

Foto bersama siswa pemenang sesi Tanya jawab

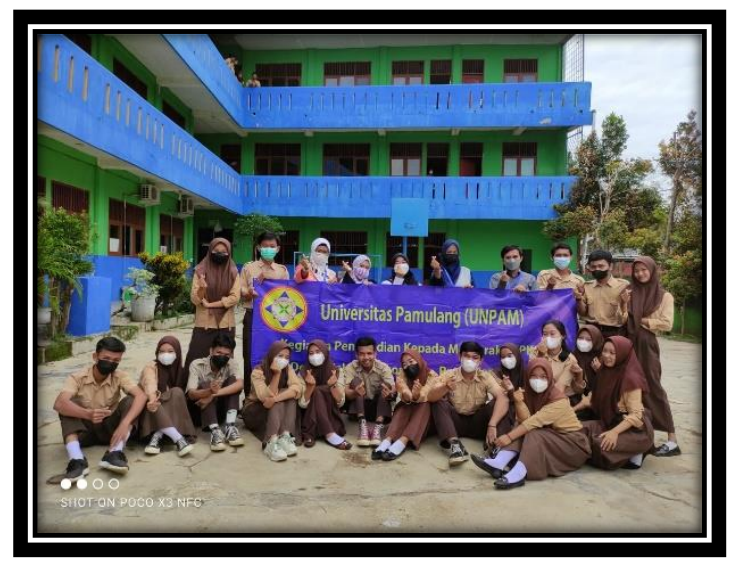

Foto bersama siswa/I SMK Bina Harapan Ciseeng

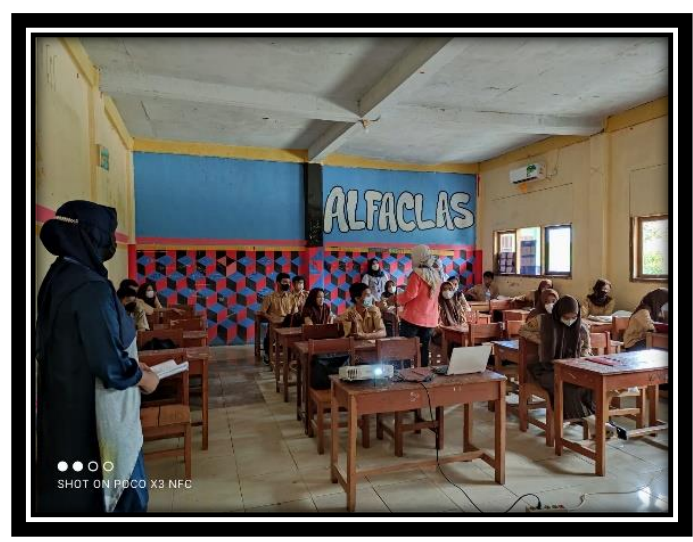

Pemberian materi oleh Ibu Tutri Indraswari S.E., M.M

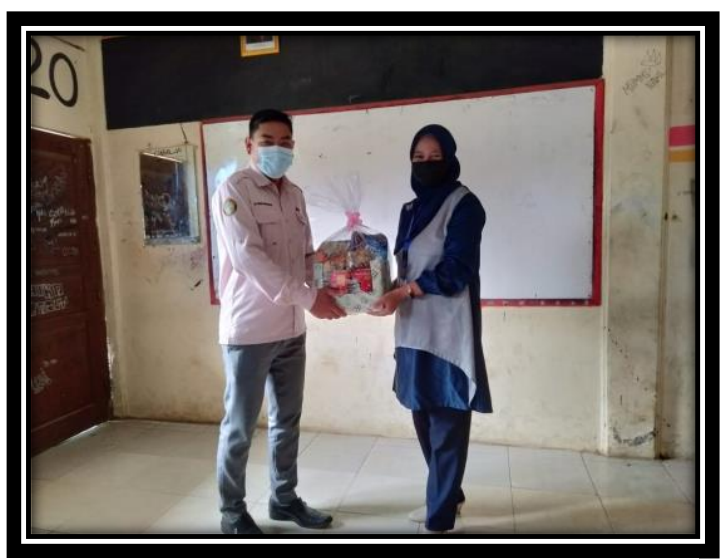

Pemberian bingkisan oleh ketua PKM, Ayu Puspa Lestiyadi, S.E., M.M kepada Wakil Kepala Sekolah SMK Bina Harapan Ciseeng

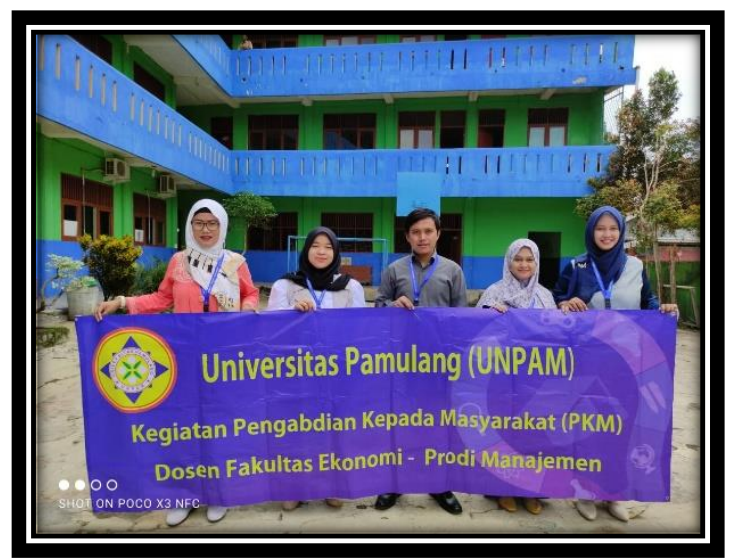

Foto bersama dosen Universitas

Pamulang 